\title{
KEMAMPUAN KOMUNIKASI MATEMATIS DAN RESPON SISWA PADA MODEL PROBLEM BASED LEARNING BERBASIS ETNOMATEMATIKA
}

\author{
Lukky Fadillah $^{1)}$, Toto Subroto ${ }^{2)}$, Ena Suhena Praja ${ }^{3)}$ \\ ${ }^{1)}$ Universitas Negeri Semarang, Semarang, Indonesia; \\ ${ }^{23))}$ Universitas Swadaya Gunung Jati, Cirebon, Indonesia \\ fadillahlukky1993@gmail.com, ; totosubroto@gmail.com, suhenaena@yahoo.co.id
}

\begin{abstract}
This research aims to determine the differences in mathematical communication skills between students who use problem based learning model based on ethnomatematics with conventional learning, and students' responses to learning by using Problem Based Learning model based on ethnomatematics. The method used in this research is experimental research design using design patterns non-equivalent control group design and sampling techniques using purposive sampling. The population in this research were all students of class VIII in one of the Junior High School in Kuningan regency, West Java 2016/2017 school year by five class and samples in this research were class VIII E as the experimental class and class VIII B as the control class respectively 20 students. The results showed that there were differences in mathematical communication skills between students who learned using problem based learning model based on ethnomatematics with conventional learning after being given treatment and student responses to mathematics learning by using problem based learning model based on ethnomatematics to get a positive response from students.

Keywords : Problem Based Learning, Etnomathematics, Mathematical Communication Skill, Response
\end{abstract}

\begin{tabular}{|l|}
\hline \multicolumn{4}{|c|}{ ABSTRAK } \\
Penelitian ini bertujuan untuk mengetahui perbedaan kemampuan komunikasi \\
matematis antara siswa yang menggunakan model Problem Based Learning berbasis \\
etnomatematika dengan pembelajaran konvensional, dan respons siswa terhadap \\
pembelajaran dengan menggunakan model Problem Based Learning berbasis \\
etnomatematika. Metode yang digunakan dalam penelitian ini adalah eksperimen \\
dengan desain penelitian menggunakan pola desain Non Equivalent Control Group \\
Design dan teknik pengambilan sampel menggunakan Sampling Purposive. Populasi \\
dalam penelitian ini adalah seluruh siswa kelas VIII di salah satu SMP Negeri di \\
Kabupaten Kuningan Jawa Barat tahun ajaran 2016/2017 sebanyak lima kelas \\
sedangkan sampel dalam penelitian ini adalah dua kelas VIII yaitu kelas VIII E sebagai \\
kelas eksperimen dan kelas VIII B sebagai kelas kontrol yang masing-masing sebanyak \\
20 siswa. Hasil penelitian menunjukkan bahwa terdapat perbedaan kemampuan
\end{tabular}


komunikasi matematis antara siswa yang pembelajarannya menggunakan model Problem Based Learning berbasis etnomatematika dengan pembelajaran konvensional setelah diberi perlakuan dan respon siswa terhadap pembelajaran matematika dengan menggunakan model Problem Based Learning berbasis etnomatematika mendapatkan respons yang positif dari siswa.

Kata Kunci : Problem Based Learning, Etnomatematika, Kemampuan Komunikasi Matematis, Respons

\section{PENDAHULUAN}

Matematika merupakan ilmu universal yang mendasari perkembangan teknologi modern. Untuk menguasai dan memanfaatkan teknologi di masa yang akan datang diperlukan penguasaan matematika yang kuat sejak dini. Sebagian besar siswa mengalami kesulitan dalam pembelajaran matematika karena ketidakmampuannya untuk mengaplikasikan matematika ke dalam situasi kehidupan nyata. Mengaitkan pengalaman kehidupan nyata dengan ide-ide matematika dilakukan agar pembelajaran menjadi lebih bermakna. Hal ini sesuai dengan apa yang dikemukakan oleh Heuvel-Panhuizen (Mulbar, 2015) bahwa apabila belajar matematika terpisah dari pengalaman mereka sehari-hari, siswa akan cepat lupa.

Menurut Fujiati (2014, 175) menyatakan bahwa dalam proses pembelajaran matematika sebaiknya siswa diberi kesempatan memanipulasi benda-benda konkret yang dirancang secara khusus sehingga siswa dapat memahami suatu konsep matematika. Proses memahami suatu konsep matematika diperlukan kemampuan komunikasi. Komunikasi merupakan cara berbagi gagasan dan mengklarifikasi pemahaman dalam hal ini mengenai masalah matematika.

Kemampuan komunikasi menjadi penting ketika siswa melakukan diskusi secara berkelompok karena mereka akan berlatih untuk menjelaskan, menggambarkan, mendengarkan, menyatakan, menanyakan, dan bekerja sama sehingga dapat memahami konsep matematika dengan membangun pengetahuan mereka sendiri dengan bimbingan guru.

Berdasarkan studi pendahuluan yang dilakukan peneliti di salah satu SMP Negeri di Kabupaten Kuningan, Jawa Barat yaitu pada kelas VIII yang banyaknya siswa ada 20 siswa. Peneliti memberikan dua soal tes mengenai materi geomteri bangun ruang sisi datar khususnya kubus dan balok berbasis etnomatemtika dengan hasil sebagai berikut. 


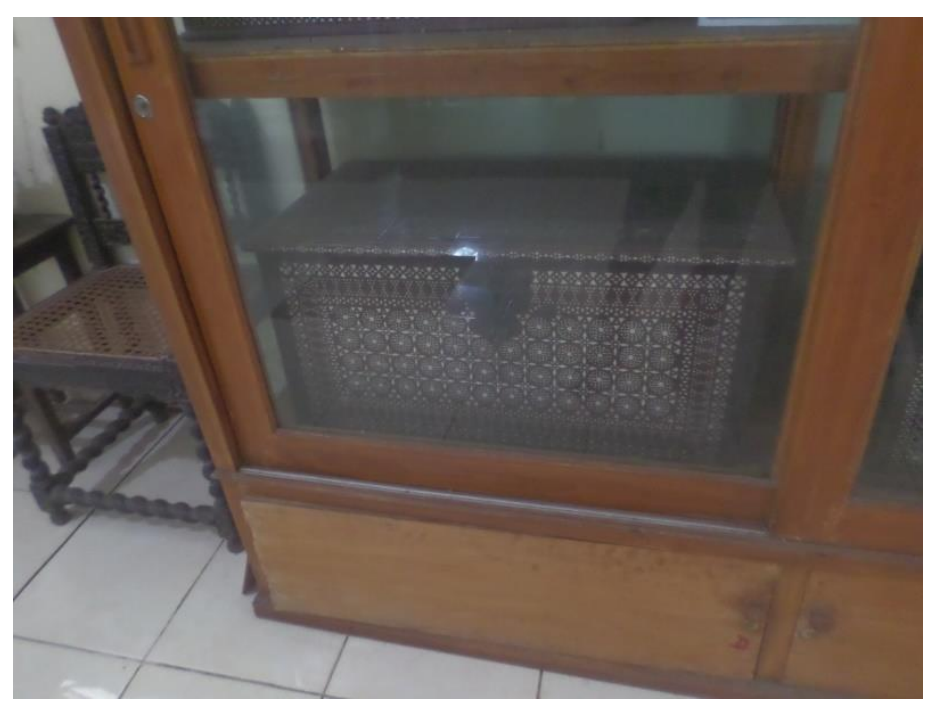

\section{Gambar 1. Peti dari Mesir}

Perhatikan Gambar 1 yang berada di dalam lemari kaca dengan seksama. Benda yang berada di dalam lemari adalah sebuah peti yang berasal dari mesir. Peti tersebut merupakan sebuah benda sejarah yang berada di Museum Benda Kuno, Keraton Kasepuhan Cirebon. Dilihat secara seksama bentu peti tersbut menyerupai balok. Apabila balok tersebut dibuka dan dibentangkan maka akan membentuk jarring-jaring balok. Buatlah dua rangkaian jaringjaring balok?

Dari jawaban salah satu siswa pada soal pertama seperti terlihat pada Gambar 2. dapat diketahui bahwa siswa belum bisa memahami apa yang disebut dengan jaring-jaring balok. Dari 20 siswa hanya ada 7 siswa yang menjawab dengan benar artinya 35\% siswa menjawab benar dan $65 \%$ siswa menjawab keliru.

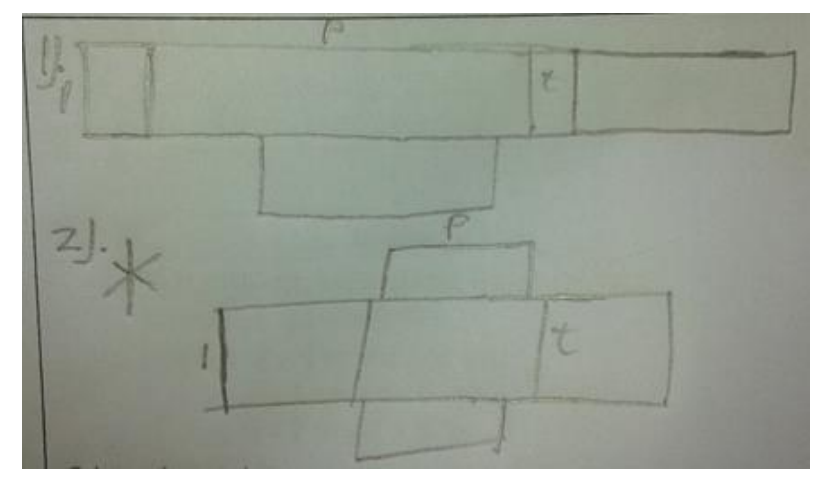

Gambar 2. Jawaban Siswa Soal Pertama 


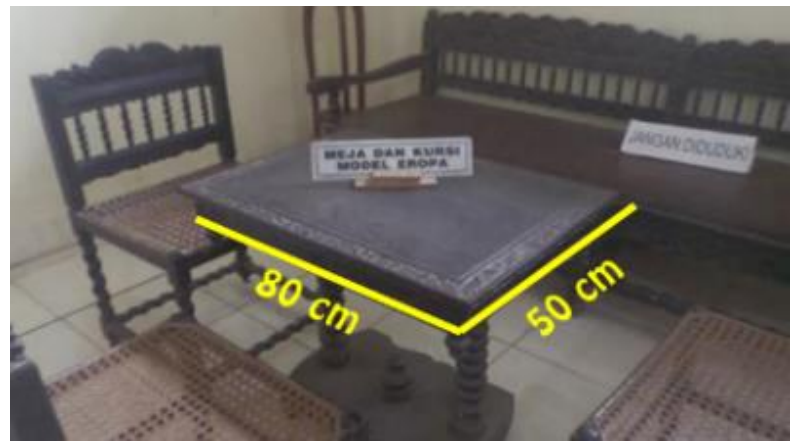

\section{Gambar 3. Meja dan Kursi Model Eropa}

Sebuah meja model eropa yang berada di Museum Benda Kuno berbentuk balok seperti terlihat pada Gambar 3. Jika diketahui meja tersebut bervolume 32.000 cm3. Hitunglah berapa luas permukaan meja tersebut!

Untuk soal kedua terdapat $20 \%$ siswa yang menjawab benar dan $80 \%$ siswa menjawab salah artinya hanya ada 4 siswa menjawab benar. Hal ini tidak terlepas dari siswa yang belum memahami cara menghutung luas permukaan balok dan volume balok seperti yang terlihat pada Gambar 4 . Kebanyakan siswa masih belum memahami apa pengertian balok. Kurangnya pemahaman siswa mengenal balok penyebab siswa tidak bisa menjawab soal tersebut.

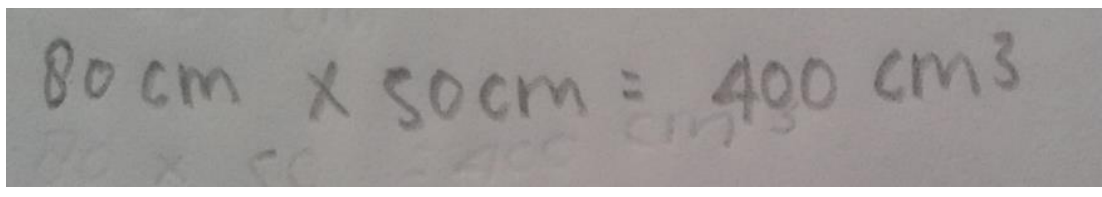

\section{Gambar 4. Jawaban Siswa Soal Kedua}

Namun, kenyataan dilapangan bahwa materi geometri kurang dikuasai sebagian siswa terlihat dari hasil uji coba yang dilakukan masih banyak siswa yang belum mengenali apa yang disebut dengan kubus dan balok baik mengenai unsur-unsurnya, jaringjaringnya, maupun rumus-rumus perhitungannya. Untuk itu perlunya pemahaman awal sebelum belajar kubus dan balok diantaranya adalah mengenai persegi dan persegipanjang. Memahami mengenai persegi dan persegi panjang menjadi prasayarat untuk belajar kubus dan balok sehingga berdasarkan pemahamn awal tersebut siswa mampu memahami pembelajaran yang diberikan.

Berdasarkan permasalahan diatas, maka perlu model pembelajaran inovatif yang dapat membantu siswa dalam meningkatkan kemampuan komunikasi. Salah satu alternatif pembelajaran yang memungkinkan dapat meningkatkan kemampuan komunikasi adalah model Problem Based Learning (PBL). 
Model PBL merupakan model pembelajaran yang menekankan kemampuan berpikir siswa melalui proses kerja kelompok yang sistematis dengan diberikan suatu masalah matematika sehingga siswa dapat memberdayakan, mengasah, menguji, dan mengembangkan kemampuan berpikirnya secara berkesinambungan. Hal ini bertujuan meningkatkan kemampuan komunikasi matematis siswa dengan cara masalah yang dikaji dalam model PBL adalah berkaitan dengan soal-soal komunikasi matematis.

Selain itu untuk meningkatkan kemampuan komunikasi matematis dapat pula dilakukan melalui pembelajaran berbasis etnomatematika. Menurut Suratno (2013, 137), etnomatematika merupakan suatu pembelajaran yang menghubungkan antara matematika dan budaya dengan tujuan untuk menunjukkan bagaimana matematika dihasilkan, ditransferkan, disebarkan, dan dikhususkan dalam berbagai macam sistem budaya seperti konsep-konsep matematika pada peninggalan budaya berupa bangunan dan benda bersejarah. Salah satu bentuk etnomatematika yang menarik untuk dieksplorasi adalah Keraton Kasepuhan, yang terletak di Cirebon, Jawa Barat. Dari sisi etnomatematika, Keraton Kasepuhan memiliki banyak potensi untuk dikaji salah satunya adalah bentuk bangunan yang banyak mengandung obyek geometri khususnya terkait bangun ruang sisi datar. Selain itu, Keraton Kasepuhan lekat dengan masyarakat, sehingga dapat dijadikan sebagai model konkrit untuk memahami matematika.

Melalui model PBL berbasis etnomatematika diharapkan siswa dapat memecahkan permasalahan dalam kehidupan nyata serta secara tidak langsung mengenal tentang budaya khususnya Keraton Kasepuhan. Model PBL sangat cocok jika permasalahnnya menggunakan pembelajaran berbasis etnomatematika. Siswa akan berdiskusi mengenai permasalah matematika yang berkonten budaya sehingga tujuan meningkatkan kemampuan komunikasi matematis akan tercapai dan pembelajaran akan bermakna karena konten masalah berkaitan dengan kehidupan disekitar masayarakat memungkinakan siswa tidak akan cepat lupa dan bosan dalam proses pembelajaran.

Adupun respons siswa digunakan untuk dapat mengukur pendapat siswa mengenai ketertarikan, perasaan senang, serta kemudahan memahami komponen-komponen antara lain isi dari pelajaran, dan format materi ajar.

\section{LANDASAN TEORI}

\section{Problem Based Learning (PBL)}

Model PBL merupakan suatu pembelajaran yang mengedepankan kepada suatu permasalahan yang harus diselesaikan secara berkelompok oleh siswa serta guru hanya sebagai fasilitator dan siswa diharapkan lebih aktif dalam mengungkapkan pendapatnya mengenai masalah yang 
diberikan. Sejalan dengan Tan (Rusman, 2014: 229) bahwa model PBL merupakan inovasi dalam pembelajaran karena dalam PBL kemampuan berpikir siswa benar-benar dioptimalkan melalui proses kerja kelompok, sehingga siswa dapat mengasah, menguji, memberdayakan dan mengembangkan kemampuan berpikirnya serta siswa dituntut untuk aktif bertanya untuk menyelesaikan masalah yang diberikan.

\section{Etnomatematika}

Etnomatematika adalah bentuk matematika yang dipengaruhi atau didasarkan budaya. Menurut LaraAlecio (Hartoyo, 2012) menyatakan salah satu bentuk pembelajaran agar siswa terikat dengan lingkungan budayanya dengan pengajaran ethnoscience, yakni topik pembelajaran yang membahas keterkaitan antara ilmu pengetahuan kealaman dengan etnik atau budaya manusia, termasuk diantaranya adalah etnomatematika. Pendapat lain menurut Zhang \& Zhang (Suratno, 2013) etnomatematika merupakan penelitian yang menghubungkan antara matematika dan budaya dengan cara dihasilkan, ditransferkan, disebarkan, dan dikhususkan dalam berbagai macam sistem budaya. Penerapan etnomatematika dalam pendidikan khususnya pembelajaran matematika diharapakan agar siswa dapat lebih memahami pentingnya nilai budaya sehingga nilai budaya yang merupakan bagian karakter bangsa tertanam sejak dini dalam diri siswa.

\section{Kemampuan Komunikasi Matematis}

Komunikasi merupakan suatu cara untuk menyampaikan pesan dari pembawa pesan kepada penerima pesan dengan tujuan untuk memberikan informasi baik secara lisan maupun tertulis. Proses pembelajaran matematika pun diperlukan komunikasi antara guru dan siswa sehingga pesan yang disampaikan oleh guru dapat memberikan informasi yang positif kepada siswa. Komunikasi dalam pembelajaran matematika disebut dengan kemampuan komunikasi matematis. Menurut Forrest (2008), kemampuan komunikasi matematis adalah kemampuan untuk mengekspresikan ide-ide matematika melalui ucapan, tulisan, dan demonstrasi; kemampuan untuk memahami, menafsirkan, dan menilai ide yang disajikan secara tertulis, lisan, atau dalam bentuk visual; kemampuan untuk membangun, menafsirkan dan menghubungkan berbagai representasi ide dan hubungannya.

Adapun indikator kemampuan komunikasi matematis siswa menurut Hendriana dan Soemarmo (2014: 29) yaitu: (1) kemampuan menjelaskan ide, situasi, dan relasi matematik, secara tulisan dengan menggunakan gambar dan ekspresi aljabar; (2) kemampuan menyatakan peristiwa sehari-hari dalam bahasa atau simbol matematika atau menyusun model matematika suatu peristiwa; (3) kemampuan membaca dengan pemahaman suatu permasalahan matematika; (4) kemampuan mengungkapkan kembali suatu uraian 
atau paragraf matematika dalam bahasa sendiri.

\section{Respons Siswa}

Respons siswa merupakan suatu reaksi sosial yang dilakukan siswa dalam menanggapi pengaruh atau rangsangan dalam dirinya dari situasi pengulangan yang dilakukan orang lain, seperti tindakan pengulangan guru dalam proses pembelajaran atau dari fenomena sosial disekitar sekolahnya. Sejalan dengan Sagala (2006: 126), respons merupakan bayangan yang menjadi kesan yang dihasilkan dari pengamatan. Kesan tersebut menjadi isi kesadaran yang dapat dikembangkan dalam hubungannya dengan konteks pengalaman waktu sekarang serta antisipasi keadaan untuk masa yang akan datang.

\section{METODE PENELITIAN}

\section{Jenis Penelitian}

Penelitian ini menggunakan penelitian kuantitaif dengan metode eksperimen. Desain penelitian menggunakan pola desain Non Equivalent Control Group Design

\section{Subjek Penelitian}

Populasi dalam penelitian ini adalah seluruh siswa kelas VIII di salah satu SMP Negeri di Kabupaten Kuningan Jawa Barat tahun ajaran 2016/2017 sebanyak lima kelas sedangkan sampel dalam penelitian ini adalah dua kelas VIII yaitu kelas VIII E sebagai kelas eksperimen dan kelas VIII B sebagai kelas kontrol yang masing- masing sebanyak 20 siswa. Kelas eksperimen menggunakan model PBL berbasis etnomatematika dan kelas kontrol menggunakan pembelajaran konvensional. Sedangkan teknik pengambilan sampel menggunakan sampling purposive dimana teknik pengambilan sampel dengan pertimbangan-pertimbangan tertentu.

\section{Teknik Pengumpulan Data dan Teknik Analisis Data}

Teknik pengumpulan data dalam penelitian ini adalah tes kemampuan komunikasi matematis dan angket respons siswa.

\section{HASIL PENELITIAN DAN PEMBAHASAN}

Hasil

Berikut ini akan dijelaskan hasil dan pembahasan beberapa hal yang berkaitan dengan model PBL berbasis etnomatematika terhadap kemampuan komunikasi matematis dan respons.

Untuk analisis perbedaan kemampuan komunikasi matematis antara siswa yang menggunakan model PBL berbasis etnomatematika dengan pembelajaran konvensional sebelumnya dilakukan terlebih dahulu uji prasyarat yaitu uji normalitas terhadap data kemampuan komunikasi matematis siswa. Hasil uji normalitas data menunjukkan bahwa data kemampuan komunikasi matematis siswa tidak berasal dari populasi yang berdistribusi normal. Karena tidak memenuhi asumsi normalitas maka data kemampuan komunikasi matematis di analisis menggunakan uji non-parametrik uji Mann Whitney $U$. 
Tabel 1. Hasil Uji Mann Whitney U Pretes dan Postes

\begin{tabular}{ccc}
\hline Data & Mann-Whitney $\boldsymbol{U}$ & Sig. (2-tailed) \\
\hline Pretes & 132,000 & 0,066 \\
\hline Postes & 118,500 & 0,027 \\
\hline
\end{tabular}

Berdasarkan Tabel 1 hasil output uji Mann Whitney $U$ data pretest pada kelas eksperimen dan kelas kontrol, diperoleh nilai setengah dari Asymp. Sig. (2-tailed) sebesar 0.033 lebih besar dibandingkan setengah dari
0.05 yaitu 0.25 atau $0.033>0.025$. Artinya bahwa pretest kemampuan komunikasi matematis siswa baik kelas eksperimen maupun kelas kontrol tidak terdapat perbedaan hal ini dikarenakan pada kelas eksperimen dan kelas kontrol belum diberikan perlakuan.

Tabel 2. Data Hasil Tes Kemampuan Komunikasi Matematis Siswa

\begin{tabular}{lllll}
\hline \multirow{2}{*}{ Data Statistik } & \multicolumn{2}{l}{ Kelas Kontrol } & \multicolumn{2}{l}{ Kelas Eksperimen } \\
\cline { 2 - 5 } & Pretest & Posttest & Pretest & Posttest \\
\hline Jumlah Siswa & 20 & 20 & 20 & 20 \\
\hline Rata-rata & 20.35 & 61.70 & 26.70 & 79.60 \\
\hline Peningkatan Rata-rata & 41.35 & & 52.90 & \\
\hline Varian & 417.29 & 687.91 & 204.54 & 100.46 \\
\hline Standar Deviasi & 20.43 & 26.23 & 14.30 & 10.02 \\
\hline Nilai Tertinggi & 67 & 89 & 50 & 92 \\
\hline Nilai Terendah & 1 & 7 & 8 & 59 \\
\hline
\end{tabular}

Sedangkan Tabel 2 hasil output uji Mann Whitney $U$ data posttest pada kelas eksperimen dan kelas kontrol, diperoleh nilai setengah dari Asymp. Sig. (2-tailed) sebesar 0.0135 lebih kecil dibandingkan setengah dari 0.05 yaitu 0.25 atau $0.0135<0.025$. Artinya bahwa posttest kemampuan komunikasi matematis siswa baik kelas eksperimen maupun kelas kontrol terdapat perbedaan. Hal ini menunjukan bahwa setelah diberi perlakuan kemampuan kedua kelas baik kelas eksperimen maupun kelas kontrol memiliki perbedaan.
Selain itu, untuk mengetahui perbedaan kemampuan komunikasi matematis siswa antara kelas eksperimen dan kelas kontrol maka peneliti menggunakan data hasil tes kemampuan komunikasi matematis seperti terlihat pada Tabel 3. Dari hasil tes kemampuan komunikasi matematis siswa antara kelas eksperimen dan kelas kontrol terlihat bahwa peningkatan ratarata pada kelas eksperimen sebesar 52.90. Sedangkan peningkatan rata-rata pada kelas kontrol sebesar 41.35. Hal ini menunjukan bahwa kemampuan komunikasi matematis kelas eksperimen lebih baik dibandingkan kelas kontrol. 
Artinya bahwa pembelajaran dengan menggunakan model PBL berbasis etnomatematika lebih baik dibandingkan dengan pembelajaran konvensional. Hal ini sejalan dengan Achor (2009) bahwa hasil belajar dan daya ingat siswa pada saat pembelajaran dengan menggunakan etnomatematika lebih tinggi dibandingkan hasil belajar dan daya ingat siswa yang pembelajarannya menggunakan pembelajaran yang konvensional.

Adapun hasil respons siswa dilakukan dengan pemberian angket kepada siswa di kelas eksperimen yaitu sebanyak 20 responden. Pemberian angket digunakan untuk mengetahui bagaimana respons siswa terhadap proses pembelajaran matematika dengan menggunakan model PBL berbasis etnomatematika. Angket respons tersebut terdiri dari 16 pernyataan yang memuat 8 pernyataan positif dan 8 pernyataan negatif. Hal ini diperlukan kekonsistenan responden untuk menjawab setiap pernyataan angket respons siswa.

Dari hasil analisis hasil angket respons siswa yang telah dilakukan pada kelas eksperimen, diperoleh data hasil respons siswa terhadap pembelajaran matematika dengan menggunakan model PBL berbasis etnomatematika. Untuk pernyataan positif didapat persentase sebesar $84.25 \%$ dengan interpretasi sangat kuat sedangkan untuk pernyataan negatif didapat persentase sebesar $68.00 \%$ dengan interpretasi kuat. Selain itu hasil rekapitulasi rata-rata hasil angket respons siswa adalah sebesar $76.13 \%$ dengan interpretasi kuat.

Dari data hasil angket respons siswa tersebut menunjukkan respons yang sangat baik terhadap pembelajaran matematika dengan menggunakan model PBL berbasis etnomatematika. Model PBL berbasis etnomatematika memberikan kesempatan siswa untuk saling bertukar pendapat mengenai permasalahan yang diberikan. Penerapan diskusi kelompok dalam pembelajaran memudahkan siswa untuk menyelesaikan soal-soal yang diberikan oleh guru. Hal ini disebabkan karena saat mengerjakan permasalahan dikerjakan secara diskusi kelompok saling berkomunikasi dan bertukar infomasi serta konten berbasis budaya membuat respons siswa terhadap pembelajaran matematika menjadi lebih bermakna.

Siswa memberikan respons yang positif pada pembelajaran dengan menggunakan model PBL berbasis etnomatematika karena siswa merasa pembelajaran yang diajarkan memberikan minat yang baik, pembelajaran lebih menyenangkan dengan adanya unsur budaya, materi yang diajarkan ringan dan mudah dipahami, dan pembelajaran menjadi lebih bermakna. Hal ini sejalan dengan Uloko dan Imoko (Achor, 2009), bahwa etomatematika memberikan terobosan untuk menarik minat siswa dalam mempelajari matematika sehingga lebih menyenangkan dan fresh bagi generasi saat ini sehingga pembelajaran matematika akan lebih inovatif. 


\section{SIMPULAN DAN SARAN}

\section{Simpulan}

Berdasarkan hasil penelitian dan pembahasan yang telah dikemukakan, maka hasil penelitian ini dapat disimpulkan sebagai berikut: (1) terdapat perbedaan kemampuan komunikasi matematis antara siswa yang menggunakan model PBL berbasis etnomatematika dengan pembelajaran konvensional setelah diberi perlakuan. (2) Respons siswa terhadap pembelajaran matematika dengan menggunakan model PBL berbasis etnomatematika mendapatkan respons yang baik dari siswa terlihat dari hasil rekapitulasi rata-rata hasil angket respons siswa adalah sebesar $76.13 \%$ dengan interpretasi kuat.

\section{Saran}

Berdasarkan uraian diatas yang
telah dikemukakan mengenai kesimpulan di atas, maka peneliti mengajukan beberapa saran yaitu (a) guru dapat menerapkan model PBL berbasis etnomatematika dalam pembelajaran, karena respons siswa terhadap model tersebut sangat baik dan positif, (b) Penelitian ini etnomatematika adalah sebagai basis model PBL, diharapkan bagi penelitian selanjutnya etnomatematika digunakan secara keseluruhan untuk mengukur kemampuan komunikasi matematis siswa.

\section{DAFTAR PUSTAKA}

Achor, E. (2009). Effect of Ethnomathematics Teaching
Approach On Senior Secondary Students' Achievement and Retention In Locus. Educational Research and Review, 4(8), 385390.

Fujiati, I. (2014). Keefektifan Model POGIL Berbantuan Alat Peraga Berbasis Etnomatematika terhadap Kemampuan Komunikasi Matematis. UNNES Journal of Mathematics Education, 3(3), 174180.

Forrest, D.B. (2008). Communication Theory Offers Insight into Mathematics Teachers' Talk. Jurnal the Mathematics Educator, 18(2), $23-32$.

Hartoyo, A. (2012). Eksplorasi Etnomatematika Pada Budaya Masyarakat Dayak Perbatasan Indonesia Malaysia Kabupaten Sanggau Kalbar. Jurnal Penelitian Pendidikan, 13(1): 14-23.

Hendriana, $\mathrm{H}$ dan Soemarmo, U. (2014). Penilaian Pembelajaran Matematika. Bandung: PT Refika Aditama.

Mulbar, U. (2015). Pengembangan desain pembelajaran Matematika dengan memanfaatkan sistem sosial masyarakat.

Cakrawala

Pendidikan, 2(2), 278-287

Mullis. (2012). TIMSS 2011 International Results in Mathematics. TIMSS \& PIRLS International Study Center, Lynch School of Education, Boston College Chestnut Hill, MA, USA and International Association for the Evaluation of Educational Achievement (IEA). Amsterdam, Netherlands. 
OECD. (2012). PISA 2012 Results in Focus: What 15-year-olds know and what they can do with what they know.

Rusman. (2014). Model-model Pembelajaran: Mengembangkan Profesionalisme Guru. Jakarta: Rajawali Pers.

Sagala, S. (2006). Konsep dan Makna Pembelajaran Untuk Membantu Memecahkan Masalah Problematika Belajar dan Mengajar. Bandung: Alfabeta.
Sugiyono. (2012). Metode Penelitian Kuantitatif Kualitiatif dan $R \& D$. Bandung: Alfabeta.

Suratno, J. (2013). Program Penelitian Ethnomathematics dan Implikasi Langsungnya dalam Pembelajaran Matematika. Jurnal Penelitian dan Pembelajaran Matematika, 6(2), 137-143. 